\title{
Scientists think, too
}

IMAGES of science and the scientist and of engineering and the engineer are much discussed at present. The most recent issue of Physics Today contains W. A. Fowler's Presidential Address to the American Physical Society in which some ideas on brushing up the physicist's image are put forward. British engineers, deeply concerned at what they believe is society's lowly rating of them, have been puzzling for some time over how they can better present their profession. And the Spring issue of Science for People, the magazine of the British Society for Social Responsibility in Science, is devoted to images of science; we are told that scientific work, being subject to an extreme division of labour, 'tends to be boring, unfulfilling, alienating and unhealthy like most jobs in a capitalist society ... Being a scientific worker means working in a patriarchal, repressive hierarchy, often in bad working conditions, without control over the fruits of one's labour'.

Images are, of course, needed for a variety of purposes. The student will see the scientific profession in a certain light and will accordingly decide whether or not to contemplate a scientific career. The industrial employer will have a different sort of perception of science related to value to the company. The politician will want to know whether scientists and technologists are basically trustworthy in their advice or whether they are prone to empire building and self-serving pronouncements. The layman, relying more and more on science and technology to deliver the goods, will have his or her own view of whether the scientist and technologist substantiate their claims. Occasionally in all of these directions we can be pleasantly surprised at the reservoir of goodwill, trust and interest which remains.

But there is one image which is in danger of being submerged amidst the recent frenzy to project science as still valuable and scientists as (in Fowler's words) capable, practical, ingenious, innovative and at the same time human beings. That is the image of scientists as thinkers. The public still remembers Einstein and recognises him as a great thinker, but is science in general considered to be a thinking profession? Of course this image is not necessarily one which will be for mass-consumption, but it is an important one nevertheless, because other people in our society most certainly regard themselves as thinkers and it is important that they do not dismiss scientists as doers only, and therefore of not being capable of participating in sensible general discussions on broad matters of policy. This has happened to a large extent in Britain already, with precious little action from bodies which are supposed to have the scientist's interest at heart. There is deplorably little involvement of the scientist in what migh be called 'the life of the nation' and the process is, of course, self-reinforcing: the more the exclusion, the smaller the number of those who can talk sense.

What to do to establish toeholds? Clearly anything involving the expenditure of large sums is not going to be feasible in the near future, so we may have to rule out such desirable ideas as seconding scientists to work with politicians, or the establishment of new interdisciplinary institutions. There still remain, however, opportunities within the media-the arch-purveyors of image. Last year there was great satisfaction that a young biologist should be asked to deliver the BBC's Reith Lectures. But very few scientists are allowed to express their own views in any extended way either on work they are involved in themselves or on more general matters. The formula is generally that scientists, if allowed to speak or write at all for the general public, do so almost invariably through short extracts only, with a journalist or reporter on hand to explain what the scientist means. There is nothing fundamentally wrong with this format (not that many professors in the humanities would stand for it), but in the absence of more extended contributions in the columns of serious newspapers, in magazines and in radio talks, the impression is undoubtedly left that scientists aren't really capable of stringing together more than a few dozen words, are only worth hearing on their very narrow speciality and are best not disturbed in their busy life of doing things. It is time the thinking side of science was given a more public airing. 